\title{
Social capital in the system of corporate sustainability
}

\author{
Svetlana Orekhova*, Vera Zarutskaya, and Yulia Bausova \\ Ural State University of Economics, 8 Marta/NarodnayaVolya Str., 62/45, 620144 Ekaterinburg, \\ Russia
}

\begin{abstract}
Social capital is a key factor in corporate sustainability in the ecosystem era. Analysis of the theoretical background reveals that social capital can function at all levels of economy - from the individual to the state. Therefore, social capitalis on the one hand an independent resource generating income. On the other hand, social capital provides access to the ecosystem actors' resources.Oftentimes stakeholders underestimate social capital because of its intrinsic "public good" quality and limit investment in it. The ecosystem social capital structure includes several dimensions. The elements of each dimension are applied to strengthen the performance of corporate sustainability indicators.
\end{abstract}

\section{Introduction}

Amid a stressful epidemiological situation, corporate sustainability is undergoing a varietyof transformations. The most urgent of them are the problems of socio-economic interaction of firms in the context of social distancing and a new wave of technological changes, as well as the choice of priorities such as ecology, society or economy.

The concept of corporate sustainable development is a microeconomic embodiment of an idea first voiced in 1974 at the UN andclarified in 1987 [1]. John Elkington [2] is believed to coin the term "triple bottom line" (TBL, 3BL) in 1994, which consists of three parts: financial (profit), social (people) and environmental, or ecological (planet).

Corporate sustainability should be interpreted not only as a company's approach to ensuring its long-term development, but also as an increase in the viability of its ecosystems [3]. According to Dyllick and Hockerts [4], "corporate sustainability can accordingly be defined as meeting the needs of a firm's direct and indirect stakeholders (such as shareholders, employees, clients, pressure groups, communities, etc.), without compromising its ability to meet the needs of future stakeholders as well." The trinity of goals implies a company having three groups of capital (Table 1).

\footnotetext{
${ }^{*}$ Corresponding author: bentarask@list.ru
} 
Table 1.Types (structure) of corporate capital [4]

\begin{tabular}{|c|c|c|c|}
\hline $\begin{array}{c}\text { Aspect of } \\
\text { sustainability }\end{array}$ & Economic capital & Natural capital & Social capital \\
\hline $\begin{array}{l}\text { What is it? } \\
\text { (essence) }\end{array}$ & $\begin{array}{l}\text { 1) financial; } \\
\text { 2) material); } \\
\text { 3) non-material } \\
\text { (reputation, know- } \\
\text { how, organizational } \\
\text { procedures) }\end{array}$ & $\begin{array}{l}\text { Natural resources and } \\
\text { ecosystem services }\end{array}$ & $\begin{array}{l}\text { 1) human capital (skills, } \\
\text { motivation and loyalty of } \\
\text { employees and business } \\
\text { partners); } \\
\text { 2) societal capital and } \\
\text { quality of public services }\end{array}$ \\
\hline $\begin{array}{l}\text { Sustainability } \\
\text { (what } \\
\text { sustainability } \\
\text { implies) }\end{array}$ & $\begin{array}{l}\text { Company can } \\
\text { guarantee a } \\
\text { continuous and } \\
\text { sufficient cash flow to } \\
\text { provide liquidity, } \\
\text { while producing } \\
\text { stable above-average } \\
\text { returns for their } \\
\text { shareholders }\end{array}$ & $\begin{array}{l}\text { Companies: } \\
\text { 1) utilize exclusively } \\
\text { natural resources; } \\
\text { 2) are not involved in } \\
\text { activities that can } \\
\text { compromise the quality } \\
\text { of ecology }\end{array}$ & $\begin{array}{l}\text { Companies manage social } \\
\text { capital in such a way that } \\
\text { stakeholders are able to } \\
\text { recognize its motivation } \\
\text { and generally accept the } \\
\text { company's system of } \\
\text { values }\end{array}$ \\
\hline
\end{tabular}

Thus, social capital is one of the crucial conditions of corporate sustainability.

In the present study, the authors focus on the formation of social capital as it underlies the long-term success of business in ecosystems, ensures the interaction between stakeholders and ultimately affects the ethics of business (including social and environmental aspects) and its performance.

\section{Method: Scientometric and terminological analysis of social capital}

A growing interest in the phenomenon of social capital among researchers was recorded in the 1990s, and it has significantly increased in recent years (Table 2).

Table 2. Distribution of academic studies on social capital in 1975-2019 [5-7]

\begin{tabular}{|l|c|l|c|l|c|}
\hline \multicolumn{2}{|c|}{ WebofScience } & \multicolumn{2}{c|}{ Scopus } & \multicolumn{2}{c|}{ RSCI (since 1990) } \\
\hline Research domain & $\begin{array}{c}\text { Number } \\
\text { of } \\
\text { publicati } \\
\text { ons }\end{array}$ & Research domain & $\begin{array}{c}\text { Number of } \\
\text { publications }\end{array}$ & $\begin{array}{l}\text { Research } \\
\text { domain }\end{array}$ & $\begin{array}{c}\text { Number of } \\
\text { publications }\end{array}$ \\
\hline $\begin{array}{l}\text { Business } \\
\text { Economics }\end{array}$ & $\begin{array}{c}5,142 \\
(26.2 \%)\end{array}$ & Social Sciences & $\begin{array}{c}14,276 \\
(56.3 \%)\end{array}$ & $\begin{array}{c}\text { Economics. } \\
\text { Economic } \\
\text { sciences }\end{array}$ & $\begin{array}{c}2,724 \\
(80.1 \%)\end{array}$ \\
\hline Sociology & $\begin{array}{c}2,233 \\
(11.4 \%)\end{array}$ & $\begin{array}{l}\text { Business } \\
\text { Management and } \\
\text { Accounting }\end{array}$ & $\begin{array}{c}5,373 \\
(21.2 \%)\end{array}$ & Sociology & $\begin{array}{c}2,596 \\
(76.4 \%)\end{array}$ \\
\cline { 1 - 2 } $\begin{array}{l}\text { Social science } \\
\text { anothertopics }\end{array}$ & $\begin{array}{c}1,719 \\
(8.7 \%)\end{array}$ & $\begin{array}{l}\text { Economics, } \\
\text { Econometrics and } \\
\text { Finance }\end{array}$ & $\begin{array}{c}3,419 \\
(13,5 \%)\end{array}$ & & 3,399 \\
\hline $\begin{array}{l}\text { Total on the } \\
\text { "social capital" } \\
\text { word group }\end{array}$ & 19,610 & & 25,364 & & \\
\hline
\end{tabular}

Jacobs [8] is considered the founder of the theory of social capital. The works by Bourdieu [9: 10] and Coleman [11] marked the stage of active research of this 
phenomenon, which began in the 1980s. Pierre Bourdieu described the so-called incorporated state of capital, i.e. its embodiment in individuals and relationships between them. Social networks and resources contained in them, therefore, become a form of productive capital. James Coleman analyzed how social capital affected the creation of human capital. The researcher identified the elements of social capital, such as obligations, expectations, trustworthiness of network members, information channels, norms and sanctions, social structure.

Based on the semantic analysis of the definitions (Table 3), we can claim that social capital is, firstly, an independent income-generating resource, and, secondly, anaggregate of a firm's means to accessing the network's other resources.

Table 3. Terminological diversity of the concept of social capital

\begin{tabular}{|c|c|c|}
\hline Author & Year & Definition \\
\hline Bourdieu [10] & 1986 & $\begin{array}{l}\text { The aggregate of the actual or potential resources which are linked to } \\
\text { possession of a durable network of more or less institutionalized } \\
\text { relationships of mutual acquaintance or recognition }\end{array}$ \\
\hline Coleman[12] & 1990 & $\begin{array}{l}\text { Social capital is not a single entity, but a variety of different entities. They } \\
\text { all facilitate certain actions of individuals who are within the structure }\end{array}$ \\
\hline Baker[13] & 1990 & $\begin{array}{l}\text { A resource that actors derive from specific social structures and then use } \\
\text { to pursue their interests; it is created by changes in the relationship among } \\
\text { actors }\end{array}$ \\
\hline $\begin{array}{l}\text { Putnam, } \\
\text { Leonardi\&Nanetti } \\
{[14]}\end{array}$ & 1993 & $\begin{array}{l}\text { Features of social organization such as networks, norms, and social trust } \\
\text { that facilitate coordination and cooperation for mutual benefit }\end{array}$ \\
\hline Fukuyama [15] & 1995 & $\begin{array}{l}\text { The existence of a certain set of informal values or norms shared among } \\
\text { members of a group that permit cooperation among them }\end{array}$ \\
\hline Portes[16] & 1998 & $\begin{array}{l}\text { The ability of actors to secure benefits by virtue of membership in social } \\
\text { networks or other social structures }\end{array}$ \\
\hline $\begin{array}{l}\text { Nahapiet\&Ghoshal } \\
{[17]}\end{array}$ & 1998 & $\begin{array}{l}\text { The sum of the actual and potential resources embedded within, available } \\
\text { through, and derived from the network of relationships possessed by an } \\
\text { individual or social unit. }\end{array}$ \\
\hline $\begin{array}{l}\text { Miles, Miles, Perrone } \\
\text { \&Edvissone [18] }\end{array}$ & 1998 & $\begin{array}{l}\text { At the firm level, social capital refers to connections with outside parties } \\
\text { that give a firm or individual access to new knowledge }\end{array}$ \\
\hline Fountain[19] & 1998 & $\begin{array}{l}\text { The contribution to institutional effectiveness of all these relationships } \\
\text { measured in terms ofeconomic performance and innovative capacity - } \\
\text { horizontally among similar firms in associations, vertically in supply } \\
\text { chains, and multidirectionally in links to sources of technical knowledge, } \\
\text { human resources, and public agencies. }\end{array}$ \\
\hline Knoke[20] & 1999 & $\begin{array}{l}\text { The process by which social actors create and mobilize their network } \\
\text { connections within and between organizations to gain access to other } \\
\text { social actors' resources }\end{array}$ \\
\hline $\operatorname{Lin}[21]$ & 1999 & $\begin{array}{l}\text { Resources embedded in social networks that can be accessed and used to } \\
\text { gain returns in instrumental actions }\end{array}$ \\
\hline Gabbay\&Leenders[22] & 1999 & $\begin{array}{l}\text { The productive set of resources, tangible or virtual, that accrue to an actor } \\
\text { through the actor's social relationships and facilitate the attainment of } \\
\text { goals }\end{array}$ \\
\hline Paldam[23] & 2000 & A set of trust, ease of cooperation and network \\
\hline Adler\&Kwon [24] & 2002 & $\begin{array}{l}\text { The goodwill available to individuals or groups. Its source lies in the } \\
\text { structure and content of the actor's social relations. Its effects flow from } \\
\text { the information, influence, and solidarity it makes available to the actor }\end{array}$ \\
\hline $\begin{array}{l}\text { Kemper, } \\
\text { Shilke\&Brettel [25] }\end{array}$ & 2013 & $\begin{array}{l}\text { Social capital will lead to information and resource benefits and that those } \\
\text { information and resource benefits will facilitate capability development. }\end{array}$ \\
\hline Leenders [26] & 2014 & $\begin{array}{l}\text { The social resources that accrue to an actor (or a set of actors). Its source } \\
\text { lies in the structure and content of the actor's social relations. These social } \\
\text { resources facilitate the attainment of goals of the actor }\end{array}$ \\
\hline $\begin{array}{l}\text { Ortiz,Donate } \\
\text { \&Guadamillas [27] }\end{array}$ & 2019 & $\begin{array}{l}\text { A resource based on knowledge, which could provide access to other } \\
\text { internal or external organizational resources. }\end{array}$ \\
\hline
\end{tabular}


The multi-element structure of social capital underlies the fact that social capital functions at all levels of the economic system: individual, household, organization and state [12; $28 ; 29]$.

\section{Results: Structure and role of social capital in the corporate sustainability}

To attain the purpose of the present research, it is necessary to examine social capital of organizations and ecosystems, in which they operate.

Social capital exhibits a number of features that differentiate it from other forms of capital. On the one hand, social capital,similar to other types of resources, can generate income, accrue and "wear out", and requires investment for reproducing itself. As any intangible asset, social capital is characterized by a relatively low level of formalization and difficulties in assessing and measuring. In addition, just like human capital, social capital has the property of "stickiness" [30], which means difficulties in transferring ownership of an asset, alienation from the owner.

Explore the structure of social capital to find out how it functions within an ecosystem and what effects it causes. At that, we assume that social capital refers to a multi-element resource incorporating assets and the network of access to them (Table 4).

Table 4. Social capital structure of inter-organizational networks [17, 23, 25]

\begin{tabular}{|c|c|}
\hline Element & Description \\
\hline \multicolumn{2}{|r|}{ Structural dimension } \\
\hline $\begin{array}{l}\text { Network } \\
\text { connections }\end{array}$ & $\begin{array}{l}\text { Established channels for the transmission of information and resources. } \\
\text { Different in intensity, direction and longevity }\end{array}$ \\
\hline $\begin{array}{l}\text { Network } \\
\text { configuration }\end{array}$ & $\begin{array}{l}\text { General structure of the connections available. } \\
\text { Characterized by the density of connections, the presence of a hierarchy } \\
\text { of nodes within networks }\end{array}$ \\
\hline \multicolumn{2}{|r|}{ Relationaldimension } \\
\hline Trust & Expectation of the agreements to be fulfilled \\
\hline Ability to cooperate & Willingness and ability to cooperate \\
\hline Norms & $\begin{array}{l}\text { A socially defined right to control someone's action by the entire group of } \\
\text { participants. Specific behavior shared by all network members }\end{array}$ \\
\hline Obligations & $\begin{array}{l}\text { Commitments to take particular actions in the future. Expectations arising } \\
\text { from the relationship of individual network actors }\end{array}$ \\
\hline Identification & $\begin{array}{l}\text { Identifying yourself with a group/network. Belonging to a network that } \\
\text { represents value }\end{array}$ \\
\hline \multicolumn{2}{|r|}{ Cognitivedimension } \\
\hline $\begin{array}{l}\text { Shared codes and } \\
\text { language }\end{array}$ & A common language or way of information coding \\
\hline $\begin{array}{l}\text { Shared business } \\
\text { routines }\end{array}$ & Unified and clear procedures for handling standard situations \\
\hline
\end{tabular}

The concept of multidimensional social capital allows analyzing it from the standpoint of both a production resource and a means of access to the participants' resources within the same network [27]. The structural dimension represents the specificity of the participant's position within the ecosystem and the characteristics of the ecosystem itself. The relational dimension is linked with assets emerging due to the interaction between the ecosystem members. The cognitive dimension of social capital is also an important asset in sharing knowledge and information to create new intellectual capital for the organization [17] and the ecosystem as a whole. 
A conceptual model of the relationship between social capital and organizational performance is given in Fig. 1.

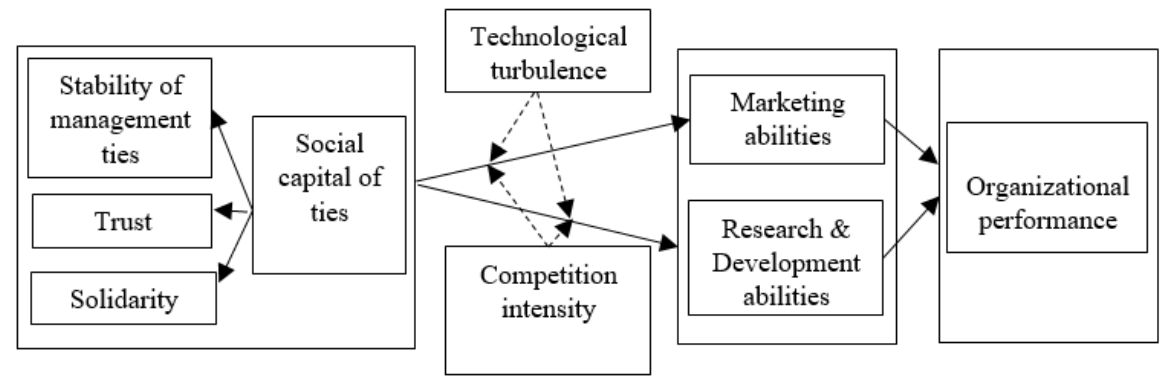

Fig. 1. Conceptual model of the relationship between social capital and organizational performance [25]

The major feature of social capital differentiating it from other resources is that it possesses properties of a public good [12]. This means that benefits of using social capital do not always belong exclusively to those who createdthese benefits.Effective norms, sanctions and the level of trust achieved when fulfilling obligations produce a positive effect for the entire ecosystem. In this regard, social capital remains an underestimated resource;there often emerges a "free rider effect", since it is not always obvious to stakeholders why to invest in such a resource.

\section{Conclusion}

Challenges of the global economic environment encourage businesses to seek new foundations for achieving corporate sustainability. Within the structure of sustainable development indicators, social capital plays a special part. The effect of social capital on organizational performance is not always evident to stakeholders, so its content should be clarified.

The core elements of social capital having the most significant influence on organizational performance are the following: 1) social ties of the management that facilitate access to external resources and information; 2) trust between the network participants; 3) readiness to cooperate (solidarity).Technological turbulence and the intensity of competition are characteristics of the environment that enhance or weaken the relationship between social capital and organizational capabilities.

The use of social capital results in a number of fundamentally new effects, such asfalling transaction costs associated with formalizing and coordinating relationships between economic actors (concluding contracts, avoiding red tape and administrative barriers, access to information, etc.)[33];providing carriers of social capital with access to benefits and resources of other members of the network; enhancing the value of the available resources;growing confidence in public institutions and society consolidation, which causes accelerated economic growth.

\section{References}

1. G. Brundtland, Our common future: The world commission on environment and development (1987)

2. J. Elkington, Cannibals with forks - Triple bottom line of 21 st century business (1997) 
3. W. Visser, D. Matten, M. Pohl, N. Tolhurst, The A to Z of Corporate Social Responsibility (2007)

4. T. Dyllick, K. Hockerts, Bus. Strategy Environ., 11, 130 (2002)

5. Web of Science Core Collection, http://webofscience.com

6. Scopus, http://scopus.com/

7. Russian Science Citation Index (RSCI), https://www.elibrary.ru

8. J. Jacobs, The Death and Life of Great American Cities (1961)

9. P. Bourdieu, Actes de la Recherche en Sciences Sociales, 31 (1980)

10. P. Bourdieu, Handbook of theory and research for the sociology of education (1986)

11. J. Coleman, Am. J. Sociol., 94, 95 (1988)

12. J. Coleman, Social sciences and contemporary world, 3, 124 (2001)

13. W. Baker, Am. J. Sociol., 96, 619 (1990)

14. R. D. Putnam, R. Leonardi, R. Y. Nanetti, Making Democracy Work: Civic Traditions in Modern Italy (1993)

15. F. Fukuyama, Trust: the social virtues and the creation of prosperity (1995)

16. A. Portes, Annu. Rev. Sociol., 24, 1 (1998)

17. J. Nahapiet, S. Ghoshal, Acad. Manag. Rev., 23 (2), 242 (1998)

18. G. Miles, R. E. Miles, V. Perrone, L. Edvinsson. Calif. Manag. Rev., 40(3), 281 (1998)

19. J. Fountain, Sci. Public Policy, 25(2), 104 (1998)

20. D. Knoke, Corporate social capital and liability, 17-42 (Kluwer, 1999)

21. N. Lin, Connections INSNA, 22 (1), 28 (1999)

22. S.M. Gabbay, R. Leenders, Corporate social capital and liability (1999)

23. M. Paldam, J. Econ. Surv., 14 (5), 629 (2000)

24. P.S. Adler, S.W. Kwon, Acad. Manag. Rev., 27, 17 (2002)

25. J. Kemper, O. Schilke, M. Brettel, J. Prod. Innov. Manag., 30(3), 589 (2013)

26. R. Leenders, Encyclopedia of Social Network Analysis and Mining (2014)

27. B. Ortiz García Navas, M.J. Donate Manzanares, F. Guadamillas Gómez, Management letters, 19(2), 151 (2019)

28. N. I. Larionova, Content and forms of realization of social capital, Cand. Sci. Econ. Diss. (2012)

29. O. L. Lushnikova, The Bulletin of KrasGAU, 6 (2013)

30. H. K. Anheier, J. Gerhards, F.P. Romo P., Am. J. Sociol., 100 (4), 859 (1995)

31. V. Radaev, Econ.Sociol., 3(4), 20 (2002)

32. V. S. Zarutskaya, S.V. Orekhova, Khristenko All-Russia sci.-pract. conf., 79, (2019)

33. F. Fukuyama, Trust: the social virtues and the creation of prosperity, 52 (2004) 